\title{
IDENTIFYING POTENTIAL CHANGE LEADERS THROUGH SOCIAL NETWORK VISUALIZATIONS
}

\author{
Piotr Andrzejak \\ Wrocław University of Economics, Wrocław, Poland \\ e-mail: piotr.andrzejak@ue.wroc.pl \\ ORCID: 0000-0002-1141-0027 \\ (C) 2019 Piotr Andrzejak \\ This is an open access article distributed under the Creative Commons Attribution-NonCommercial-NoDerivs license \\ (http://creativecommons.org/licenses/by-nc-nd/3.0/)
}

DOI: $10.15611 / \mathrm{ms} .2019 .1 .05$

JEL Classification: L2, L20, M12

\begin{abstract}
Every organizational change is considered a big challenge. Even having assured enough of the resources needed to drive the change successfully, there is also the necessity to choose the people who would be able to properly lead the change. Organizational network analysis provides some techniques and methods that help in visualizing the informal organizational structure. In the following paper some of these will be presented with the emphasis on showing the potentially key persons for the change that is planned to be developed. In the presented case study one large company was examined. The aim of the article is to analyse the problem of choosing the right people to drive change. In order to select potential change leaders there is an algorithm proposed which takes into consideration two aspects. Namely, the intensity of the archetypical leadership value of the actor, and the actor's position in the informal network. The results confirm that a relatively small group of change leaders can directly reach the majority of employees, which is one of the crucial factors for the change to succeed. The visualizations used in the study can shorten the time needed to find the right people to drive the change, and also reduce the probability of wrong guesses provided by the intuition.
\end{abstract}

Keywords: organizational change, organizational network analysis, network visualizations.

\section{Introduction}

The demanding needs of today's global markets provide the necessity for organizations to be able to drive any kind of organizational change smoothly, with as little cost as possible [Rostek, Młodzianowski, 2018]. In order to adjust to the dynamically changing markets, organizations have to determine the most appropriate way of conducting the change which covers also the designation of the right employees who become responsible for the results of the process [Beckhard, Harris 1987]. As an unavoidable practice, organizational change is distinguished by a relatively high ratio of failure [Smith 2002]. There are plenty of reasons why almost every organizational change is considered a big challenge. One of the most common is the phenomenon called resistance to change that can be present as 'a tridimensional (negative) attitude towards change which includes affective, behavioural and cognitive components' [Oreg 2006, p. 74]. Factors such as employees' experiences of uncertainty and disruptions in their sense-making [Maitlis, Sonenshein 2010; Weick 1995] are crucial for the comprehension of the nature of resistance. Even though there has been relatively a lot of material written about predicting employee change reactions [Oreg et al. 2011] and in addition to that even being familiar with the common knowledge of good change management practices (e.g. [Kotter 1996; WhelanBerry, Somerville 2010]), followers' negative change reactions can endanger the effects of an organizational change more than any other factors. Thus the identification of the proper leaders who would be able to manage employees' uncertainty and support their sensemaking in organizational change seems to be crucial [Maitlis, Sonenshein 2010].

Much has been written about the characteristics of a leader. Research provides descriptions of leadership skills in a variety of forms. Leaders can coach, intellectually stimulate, inspire, and motivate. They 
are also able to remove obstacles that might appear across the entire organizational change procedure [Saleem, Naveed 2017]. There might be a scientific gap in how to choose a group of leaders who will increase the chances for the successful change within the organization. Choosing leaders responsible for driving a change is not simple, primarily because change very often affects the entire enterprise and all of their employees [Kroenke 2016]. For small businesses the problem of identifying potential change leaders seems not be a problem at all. Management is almost always aware of the potential of the relatively small number of employees and can designate proper change leaders with a great probability of indicating the best possible options. The bigger the organization, the more significant the problem really becomes. The main goal of this study is to analyse the problem of selecting the right people to drive change by the usage of visual approaches based on social network analysis (SNA) methods. Using proper visualizations could help identify the potential change leaders who can make the implementation more effective, successful, and additionally those leaders could act as catalysts for change [Beckhard, Harris 1987; Burt 1999; Gronn 2002; Valente, Pumpuang 2007).

The traditional approaches to the selection of change leaders are based on a rigid hierarchical organization structure. Employees who are positioned relatively high in the organizational hierarchy are meant to be the most appropriate [Jacobs, Russ-Eft 2001]. Such important factors as seniority, expertise, the specific roles played in the processes or projects are frequently not taken into consideration. The process of spreading the information about a change could be described as a top-down communication which reflects a formal structure. At the beginning a small group of employees (usually high-level managers) train their direct subordinate collaborators (e.g. meddlelevel managers), who in turn train the next group of employees, lower situated in the hierarchy [Zbieg, Batorski, Żak 2016]. There are obvious weaknesses within this approach. Organizational change could be described as premeditated interventions intended to modify the functioning of an organization [Lippitt 1958]. Change leaders may need to overcome resistance from other members of their organization and encourage them to adopt new practices [Kanter 1983; Van de Ven 1986]. Therefore, change could be treated as an exercise in social influence, defined as the alternation of an attitude or behaviour by an actor in response to another actor's action [Marsden, Friedkin 1993]. The aforementioned basic social mechanism, such as influence, is very often decisive in whether to adopt new information or behaviour. Research shows that people depend mainly on the communicated experiences of others that flow through interpersonal networks [Cross et al., 2007]. It has been observed that change driven by formal networks connections resulted in failure in comparison with informal social networks which were the medium for a change [Krackhardt 1993]. Therefore using social network analysis methods and techniques in organizational studies, sometimes shortened to organizational network analysis (ONA), might be highly beneficial in solving different management problems, and also those related to the organizational changes.

\section{Theoretical background}

\section{Social Network Analysis - Visual Approaches}

The dynamical growth of the different techniques used in social network analysis is reflected in the multiple visualization approaches of the informal networks. The networks can be represented in numerous ways such as node-link diagrams, matrices, and summary tables [Foucault Welles, Xu 2018]. A wealth of mathematical literature exists regarding the visualization approaches used in social networks studies (e.g. [Battista et al. 1998]). There is even research focused on the aesthetic aspects of networks layouts and how the different forms can facilitate accurate interpretations of network graphs (e.g. [Dunne, Schneiderman 2009; Purchase 1998]). Nevertheless, only few studies analyse what impact visualization can have and how to use different interpretations in order to receive the information desired within some context of research. For instance [McGrath et al. 1997] tried to achieve some results in this area by investigating how various graph layouts representing the same network influenced students' inferences about social grouping and the importance of various actors within the network. It is important to note that this relatively well educated group of young people who had just finished a graduate course in organizational theory, were manipulated by the way the graphs were structured and organized - different layouts were presented. The impact on students' inferences was really significant.

As well as having the possibility to represent networks in textual or tabular forms, one of the most common ways of visualizing organizational networks is the graphic approach. Visualizing social networks requires gathering information about people in the network and their relationships [Sathiyanarayanan, Burlutskiy 2015]. Among the graphic forms the most commonly used visualizations are graphs. They are powerful tools for social network visualization, their meaning is clear and this technique is well constituted 
in the literature, consistently used in research for a long time [Herman et al. 2000]. There has been a number of different graph-based layouts proposed [Kobourov 2012]. Conceptually social network analysis depicts graphs as objects where network nodes are people connected by various types of relationship (trust, communication, flow of information etc.) which is represented by the graph edge. Graph visualization offers many advantages such as scalability and simplicity, at least from the conceptual point of view. Nevertheless, probably the main purpose of using graphs for social network visualizations is the existence of a well-developed, formal graph theory for the analysis of social networks [Sathiyanarayanan, Burlutskiy 2015].

Although graphs are powerful and commonly used tools for social network analysis, there are other visualization types which show the usefulness for social network visualizations (e.g. Venn or Euler diagrams, and treemaps [De Chiara, Erra, Scarano 2003; Frantz, Carley 2005]. Venn diagrams were used for the graphic representation of hierarchical file systems [De Chiara, Erra, Scarano 2003]. This representation places nodes on the surface inside Venn curves which allows users to use the proximity between categories and files to emphasise closeness and similarity. Another visualization type used to present social networks, already mentioned in this paragraph and called treemap, allows to visualize hierarchical data. So far a few visualizations have been proposed depending on the context and applications. One of the proposals used to present social network settings, shows the number of emails sent by the actor during a particular month. In this visualization a rectangle depicts a month, whereas the size of the rectangle is proportional to the number of emails sent by the given person [Frantz, Carley 2005].

Social network visualizations serve mainly two goals [Sathiyanarayanan, Burlutskiy 2015]:

- Identifying the actors of a network: the need to understand who the actors of the network are. The process of the identification the actors in the network must ensure the ability to distinguish actors easily. The general idea is to represent the actor as a node, a circle, or a rectangle.

- Understanding relationship in a network: the need to show the connections between the actors that are in some relationship. Sometimes it is necessary to show the direction of a relationship, more often it is assumed that the connection is reciprocal. For example, an edge or an intersection* might be a visual representation of such a relationship.

In this paper we take into consideration both the aforementioned aspects. We concentrate on the identification of the actors - potential change leaders - while taking into account that the position of the best leaders depends on the relationships they are involved in.

\section{Potential Change Leader - Characteristics}

Managing the change is a challenge for every manager. The personal sphere plays a key role in the entire change process. This may appear to be problematic, yet it is crucial for the change to be permanent [Kroenke 2016]. Combined with the appropriate soft skills it can ensure that the change would be properly propagated and the diffusion of information not only reaches all employees but in addition overcomes the resistance against the organizational change. Such a characteristic is demanded by enterprises across the global markets from their change leaders [Sobka 2014]. There are competences that are required from change leaders such as personnel management, especially coaching, motivating, supporting cooperation within the team. These skills differentiate change leaders from traditional managers. Contemporary organizations undergo constant changes. In order to process them successfully, an organization needs leaders within its structure. Leaders create visions, motivate and inspire employees towards the realization of the change, therefore they can be described as change leaders [Kroenke 2016]. Without change leaders, management efficiency decreases. Thus replacing managers is a usual step taken by companies which confirms why informal networks are more important from the rigid hierarchical structures in the context of organizational change.

A change leader is a person who indicates the direction of change and chooses the way in which change will be implemented, and in addition knows how, when and what tools must be used in order to keep the people motivated, which can help in successful change completion [Kroenke 2016)]. In the change process, most important are people who are affected by the change and who participate in the change, at least at some part. A leader must engage everyone. Organizational change is not only some trivial alternation such as logotype modification. Primarily it is a transformation of the key processes in crucial business areas which is usually followed by the necessary change in the mentality of the people involved [Kroenke 2016]. The definition provided is very close to the role of an archetypical leader, which is one of the potential roles, that are defined in the organizational networks among organizers and entrepreneurs [Bełz 2011]. In that interpretation, a leader is characterized as a person who supports 
engagement, motivates, modifies attitude, gives the impulse to act and develop a common understanding of the results to be obtained. In this paper we focus on this interpretation of change leaders.

For the manager who is responsible for organizational change, communication is often a key factor. Communication is directly linked with such basic management functions as planning, organizing, leading and controlling [Ober 2013]. Managers usually drive the organization realizing the aforementioned functions through the communication channels. The understanding and the attitude towards the change depends on the information that reaches people in the enterprise. A well-informed employee works more efficiently and achieves better results. Knowledge of how the information is spread in the organization is crucial, which explains why visualizing an informal structure can help in identifying the flow of the communication. There is a number of basic organizational networks, therefore from different perspectives we can observe what the informal structures may look like. Among the basic organizational network kinds there are two especially worth analysing. Namely, the communication network and the information network [Wawrzynek 2017]. As was previously described, a communication network is an informal organizational structure, defined on the existing general or contextual patterns in the organization. As the basis to form such a network one can consider questions like: How often do you talk to the following people on a given subject?, or How often do you communicate to the given person in comparison to other people in the team? Similarly, an information network is an informal structure indicating who goes to whom in order to receive advice regarding daily work. It is characterized by the following questions: How often do you get the necessary information to perform your daily work from the given person? Who usually gives you the information regarding work? Whom do you look for the information related to the daily business? or Who is the main person I receive useful information from while working on every-day tasks? The aforementioned two networks will be fundamental for the further identification of potential change leaders.

An innovatively managed enterprise must be aware that an important role in a company's success is played not only by qualified employees but also by engaged people, together with well educated, efficient managers, who act as natural leaders [Jasińska 2010]. In analysing the key features any change leader should have, it is easy to state that a universal set of com- petences is impossible to be obtained. Nevertheless, the term 'leadership' is unavoidably worth considering. The contemporary combination of leadership and management skills is of high importance and is desirable by companies [Willmanowicz 2012]. An efficient, experienced manager is able to take advantage of both aspects, mixing them in the appropriate proportions depending on the needs. This characteristic is very close, and in some places complementary to the one proposed by Bełz and was mentioned already above [Bełz 2011].

Pin-pointing employees with the highest value of archetypical leadership is one aspect of the process of the identification of potential change leaders. The second part is linked with the term 'network coverage' [Zbieg, Batorski, Żak 2016] and is connected with the term reachability and will be described shortly. Reachability is a concept of the diffusion mechanisms depicting for instance the flow of information and has been present in social network analysis since at least 1955 [Katz, Lazarsfeld 1955]. There have been numerous implementations of this idea in different areas, such as communications study [Goel et al. 2012; Watts, Dodds 2007], behavioural research [Valente, Pumpuang 2007], and marketing [Godes, Mayzlin 2009].

Organizational change is always associated with the process of exchanging information, teaching new skills, and introducing some practices that alternate the way of working across the company. Adoption to change requires a flow of information, therefore knowledge about the potential ways the information can directly or indirectly reach others in the network seems to be one of the most important issues to become familiar with, because for the purposes of change it is crucial to deliver first-hand, verifiable and stable information, and direct contact seems to be enough for the goals of this study [Zbieg, Batorski, Żak 2016]. A situation when the majority of employees dispense direct, first-hand information and the opportunity to reach the person who could simplify and facilitate the adaptation to the change, is a very desirable state. In this context, network coverage will demonstrate the proportion of the actors reached directly by the given group of people to the number of all the actors in the network [Żak, Zbieg 2014].

\section{Methods}

The research was conducted as a case study with the usage of the Netwisor ${ }^{1}$ system which is a dedicated tool for organizational network analysis and is based on

\footnotetext{
${ }^{1}$ Netwisor is an authored system, which allows conducting research based on online questionnaires. It has a built-in analytical module based on social networks' measures and a number of social networks' visualizations. Netwisor implements authors algorithms rooted in graph theory, however popular algorithms used in other Stanford University research are implemented as well. More information regarding the broader SNAP (Social Network Analysis Project) project can be found on http://snap.stanford.edu/.
} 
the survey study. All data analysis and visualizations used in this paper were obtained from Netwisor. Data for the purposes of this study were collected at a large company operating in Poland in the infrastructure branch. More than 400 respondents participated in the questionnaires. Internal Netwisor mechanisms dedicated to monitor the process of collecting data helped to achieve the relatively high response rate of $80 \%$. Table 1 shows the basic properties of the informal networks used in this study.

Table 1. Properties of the two studied informal networks

\begin{tabular}{|l|c|c|}
\cline { 2 - 3 } \multicolumn{1}{c|}{} & $\begin{array}{c}\text { Communication } \\
\text { Network }\end{array}$ & $\begin{array}{c}\text { Information } \\
\text { Network }\end{array}$ \\
\hline Number of nodes & 480 & 407 \\
\hline Number of edges & 1952 & 775 \\
\hline Density (\%) & 1.7 & 0.9 \\
\hline Average node degree & 4 & 2 \\
\hline
\end{tabular}

Source: author's own work.

Two aspects were taken into consideration while constructing the algorithm for the identification of the potential change leaders through social network visualizations:

- intensity of the archetypical leadership value of the actor,

- actor's position in the informal network.

The idea is to cover the majority of the employees - more than $50 \%$, ideally all of them, by the lowest possible number of change leaders who in addition to that condition will hold a strong archetypical leadership value.

The approach used to measure what impact the selected group of change leaders can have on their directly connected employees, was inspired by the research conducted in the area of artificial neural networks (ANN). Namely, the impact of the communication or the information transferred from the leaders group to their direct contacts in the communication or information network respectively, is the sum of the products of intensity of the archetypical leadership value of an actor and the number of direct connections of that actor within the given network. The following formula is used in order to calculate the value of leadership impact:

$$
\sum_{i=1}^{k} L_{i} I_{i}
$$

where $k$ - number of actors, $L_{i}$ - intensity of the leadership value of the $i$-th actor, $I_{i}$ - indegree of the $i$-th actor. That concept is presented in Figure 1 and is a straight analogy to the signals flow within artificial neural networks. In this scenario, the total impact of the three chosen actors $\mathrm{A}, \mathrm{B}$, and $\mathrm{C}$ is equal to $0.9 \times 1+$ $0.5 \times 1+0.4 \times 2=2.2$.

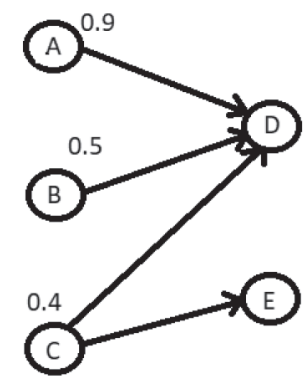

Fig. 1. Impact value calculation concept

Source: author's own work.

In the first step of analysis the employees with the strongest archetypical leadership level were selected. The arbitrary number of selected strongest leaders was chosen so as to cover more than $50 \%$ of all employees. Secondly, we analysed two informal networks, the choice was based on the literature study and includes the communication network and the information network. The visualization used for presenting these two networks is the well-known graph drawing visualization algorithm of Fruchterman-Reingold [Fruchterman. Reingold 1991]. This algorithm aims to keep the adjacent vertices close to each other, while ensuring that the vertices are not too close to each other [Kobourov 2012]. By virtue of belonging to the force-directed family of graph drawing algorithms, the Fruchterman-Reingold algorithm tends to position nodes on the surface in order to prevent some invariables regardless of the randomly chosen started points for vertices. In general, force-directed layouts such as Fruchterman-Reingold or Kamada-Kawai [Kamada, Kawai 1989] are based on the network position (e.g. centrality of the node) and therefore could be potentially useful for the identification of the important actors in the networks.

Furthermore, a comparison is made between the originally chosen, strongest archetypical leaders and the important actors from either the communication or information perspective. Actors who could be identified both as strong leaders, and important in view of communication and information flow are classified as searched change leaders with a relatively good position in both the analysed informal networks. Finally, we exchanged the weakest originally selected archetypical leader for the most important actors from the communication and information networks, yet not included in the originally selected archetypical leaders. Choosing the most important actors in the communication network and information network is 
based on the betweenness centrality measure, as it was shown that this measure could allow reaching relatively high network coverages [Zbieg, Batorski, Żak 2016]. The process of exchanging the weakest archetypical leaders proceeds until there is a significant drop in the leadership impact of the selected group of potential change leaders on the directly connected actors.

\section{Results}

In the first step employees with strongest archetypical leadership level were selected as shown in Figure 2, where $a$ presents all the actors in the organization, whilst $b$ shows 20 actors with the highest value of leadership intensity. The visualization used to show the strongest archetypical leaders is based on two features. One feature groups nodes within slices. The criterion used for grouping could be chosen arbitrary and often denotes one of the attributes of the actors, e.g. membership of a department or a team, location or seniority. The second feature, more useful in the context of the quick identification of the strongest leaders, puts nodes that have more connections, especially across different slices, closer to the centre of the graphic. Additionally, the size of the node is strictly proportional to the intensity of the archetypical leadership value.

Table 2 shows the values of the archetypical leadership intensity and indegree values for both considered informal networks. The values describing the intensity of the leadership feature were normalized

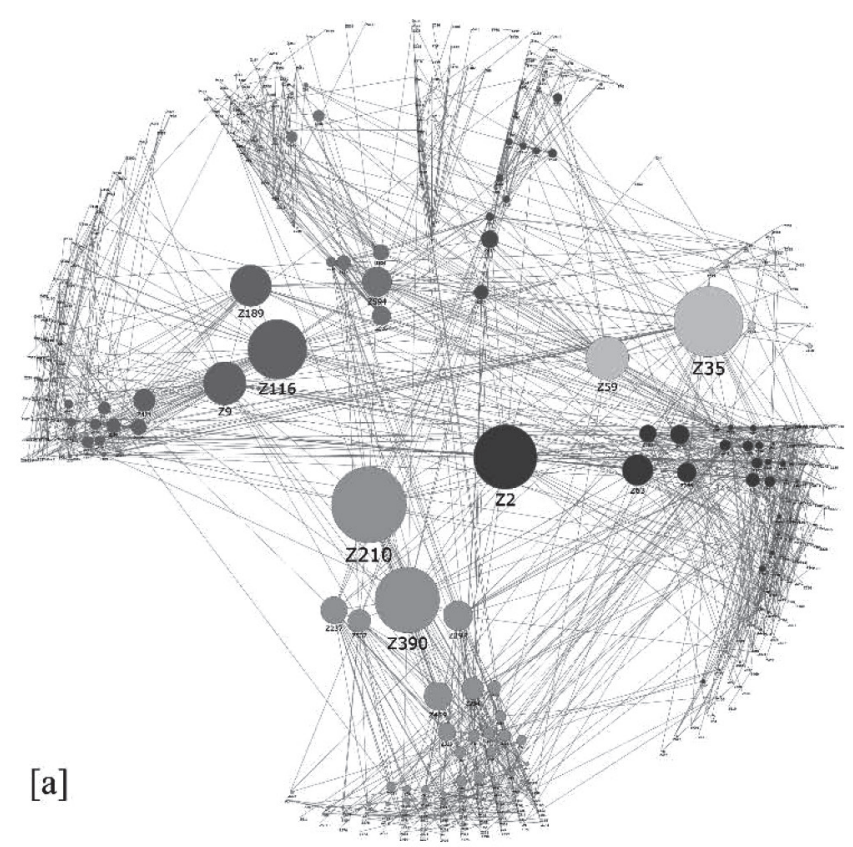

[b] in the context of the entire organization in a way that the strongest archetypical leadership feature of the actor is denoted by value 1 , other values show the

Table 2. Value of the archetypical leadership intensity

\begin{tabular}{|c|c|c|c|}
\hline Person & $\begin{array}{l}\text { Leadership } \\
\text { intensity }\end{array}$ & $\begin{array}{c}\text { Indegree } \\
\text { communication }\end{array}$ & $\begin{array}{l}\text { Indegree } \\
\text { information }\end{array}$ \\
\hline Z210 & 1.00 & 24 & 13 \\
\hline Z35 & 0.93 & 26 & 20 \\
\hline Z390 & 0.86 & 19 & 17 \\
\hline $\mathrm{Z2}$ & 0.85 & 23 & 10 \\
\hline Z116 & 0.79 & 29 & 17 \\
\hline Z59 & 0.57 & 41 & 37 \\
\hline Z9 & 0.57 & 31 & 19 \\
\hline Z189 & 0.55 & 20 & 13 \\
\hline Z63 & 0.41 & 16 & 11 \\
\hline Z594 & 0.40 & 16 & 14 \\
\hline Z297 & 0.39 & 27 & 22 \\
\hline Z458 & 0.37 & 12 & 7 \\
\hline Z237 & 0.36 & 19 & 13 \\
\hline Z537 & 0.30 & 19 & 10 \\
\hline Z254 & 0.30 & 15 & 9 \\
\hline Z471 & 0.29 & 12 & 4 \\
\hline Z266 & 0.26 & 13 & 0 \\
\hline Z71 & 0.26 & 26 & 15 \\
\hline Z526 & 0.25 & 17 & 12 \\
\hline Z515 & 0.24 & 4 & 0 \\
\hline
\end{tabular}

Source: author's own work.

Fig. 2. Archetypical leaders

Source: author's own work. 


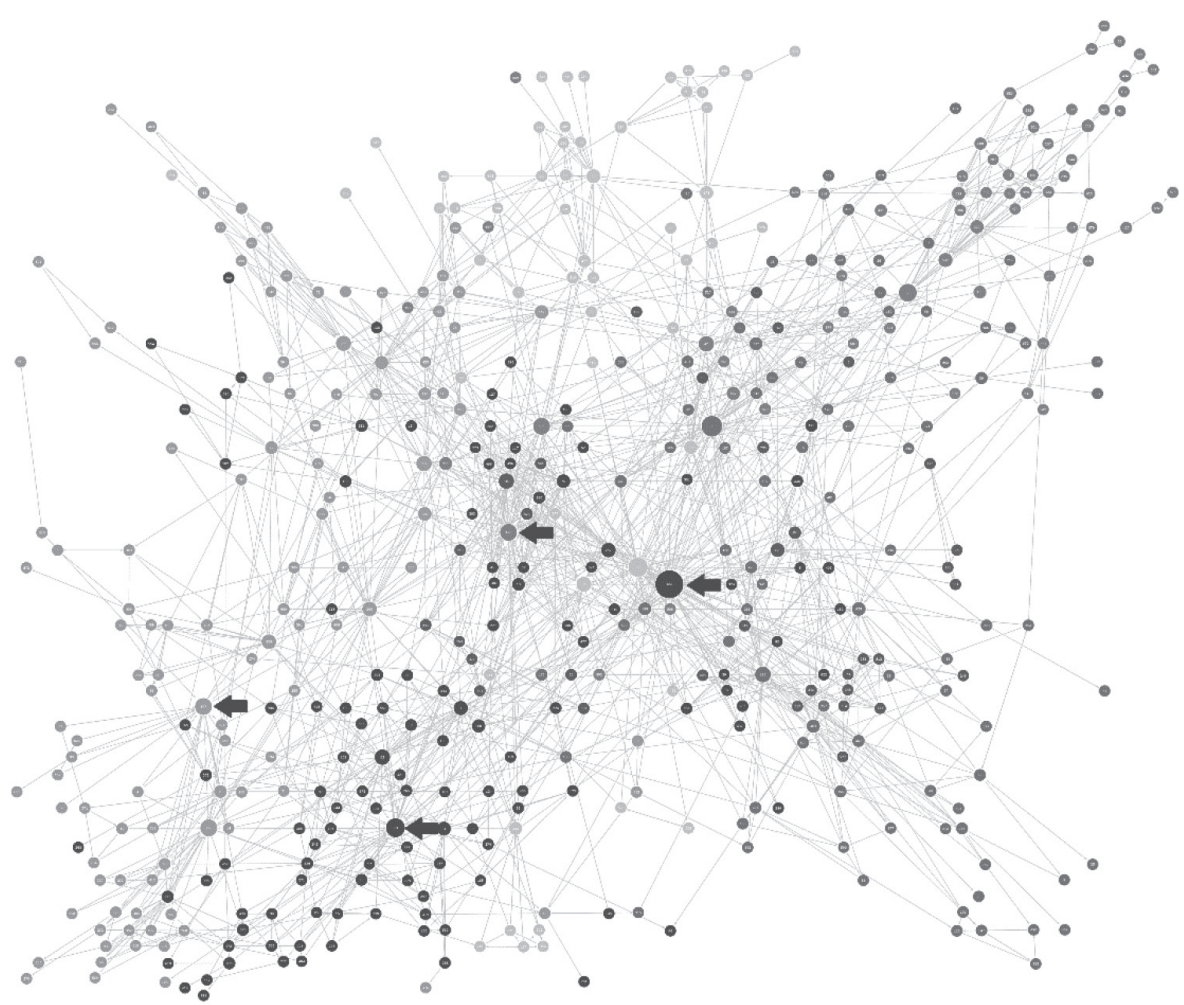

Fig. 3. Communication network

Source: author's own work.

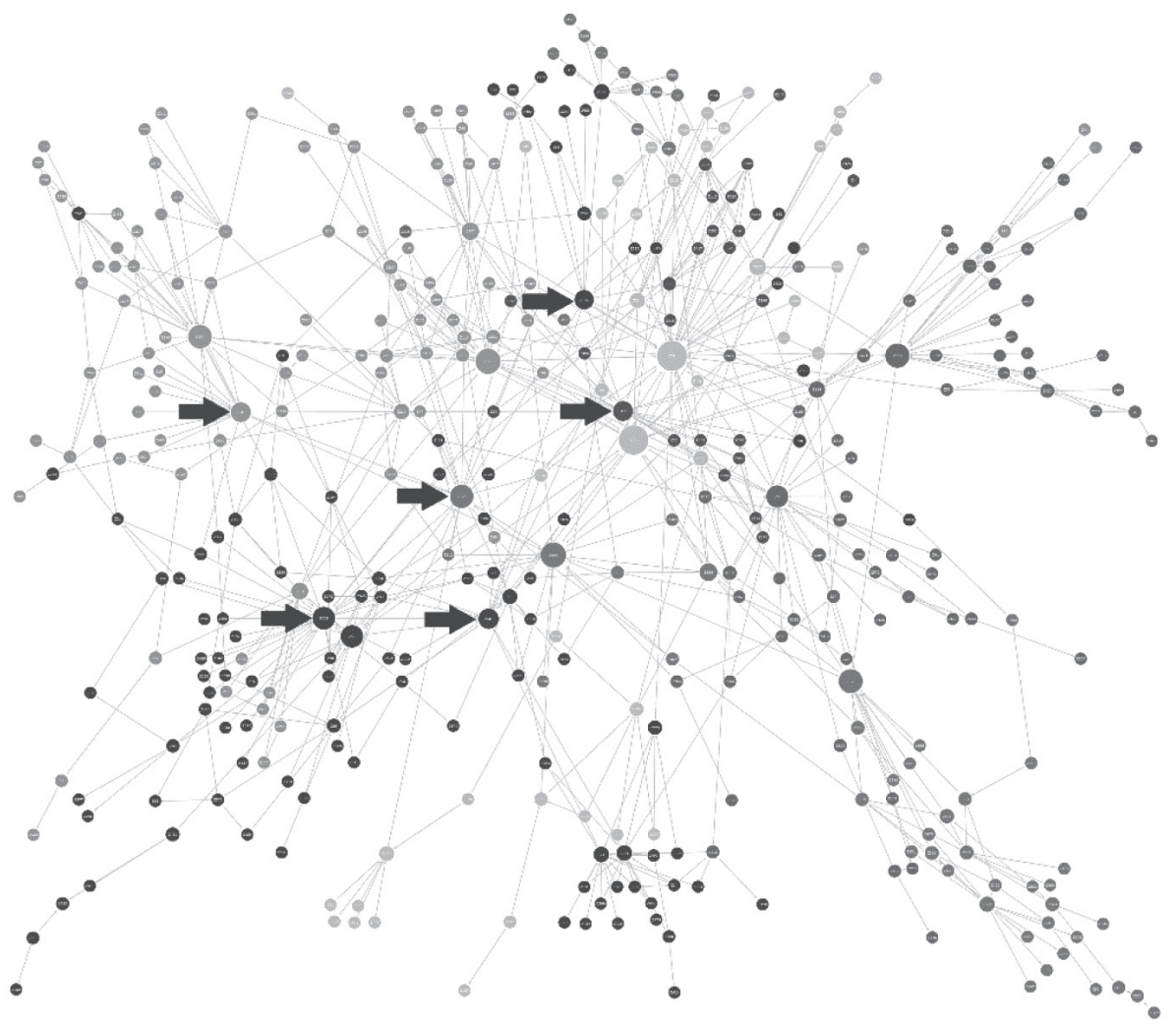

Fig. 4. Information network

Source: the author's own work. 
proportion of the strongest value. By virtue of the necessary anonymization of the data, no real names are included. In the Leadership Intensity column, the intensity of the archetypical leadership level is presented in non-increasing order for the strongest 20 leaders in the organization.

Choosing the top 20 archetypical leaders gives network coverage equal to $51 \%$ in the communication network. It is worth mentioning that selecting just 20 employees, which is roughly $4 \%$, still allowing to reach the majority of the organization by the direct links.

The second step of the process includes the visualization of the communication network and information network. Figures 3 and 4 display the communication network and information network respectively. In both aforementioned figures the blue arrows indicate the position of the actors who are important in context of the communication or information but are not included in the top archetypical leaders. In these two figures the size of the node denotes the value of normalized betweenness, normalized to the biggest betweenness value in the communication network and information network respectively. Furthermore, for the 20 actors with the highest betweenness values in the communication network, the network coverage is significantly higher than the network coverage made by the top 20 archetypical leaders and reaches $56 \%$.
Table 3. Network coverages and leadership impacts

\begin{tabular}{|l|c|c|c|c|}
\hline & \multicolumn{2}{|c|}{ Communication Network } & \multicolumn{2}{c|}{ Information Network } \\
\hline Top 20 & Communicators & Leaders & Informers & Leaders \\
\hline $\begin{array}{l}\text { Network } \\
\text { Coverage } \\
(\%)\end{array}$ & 56 & 51 & 44 & 41 \\
\hline $\begin{array}{l}\text { Leadership } \\
\text { Impact }\end{array}$ & 216 & 223 & 110 & 147 \\
\hline
\end{tabular}

Source: author's own work.

The idea to improve the combinations of network coverage and leadership impact for the selected originally 20 actors, based on their highest leadership value, require replacing the weakest actors from Table 2 by the strongest communicators and informers. The initial approach selects both strong communicators and informers if there are any. Figures 5 and 6 demonstrate how network coverage and leadership impact alter by replacing the given number of the weakest originally selected archetypical leaders by the strongest communicators and informers. The results show that by the replacement of the five weakest originally selected archetypical leaders, the network coverage increases from $51 \%$ to $53 \%$ for the communication network and from $41 \%$ to $45 \%$ for the information network, whereas the leadership impact remains almost on the same level. For the communication network leadership impact decreases by only $0.7 \%$, while for the information network we

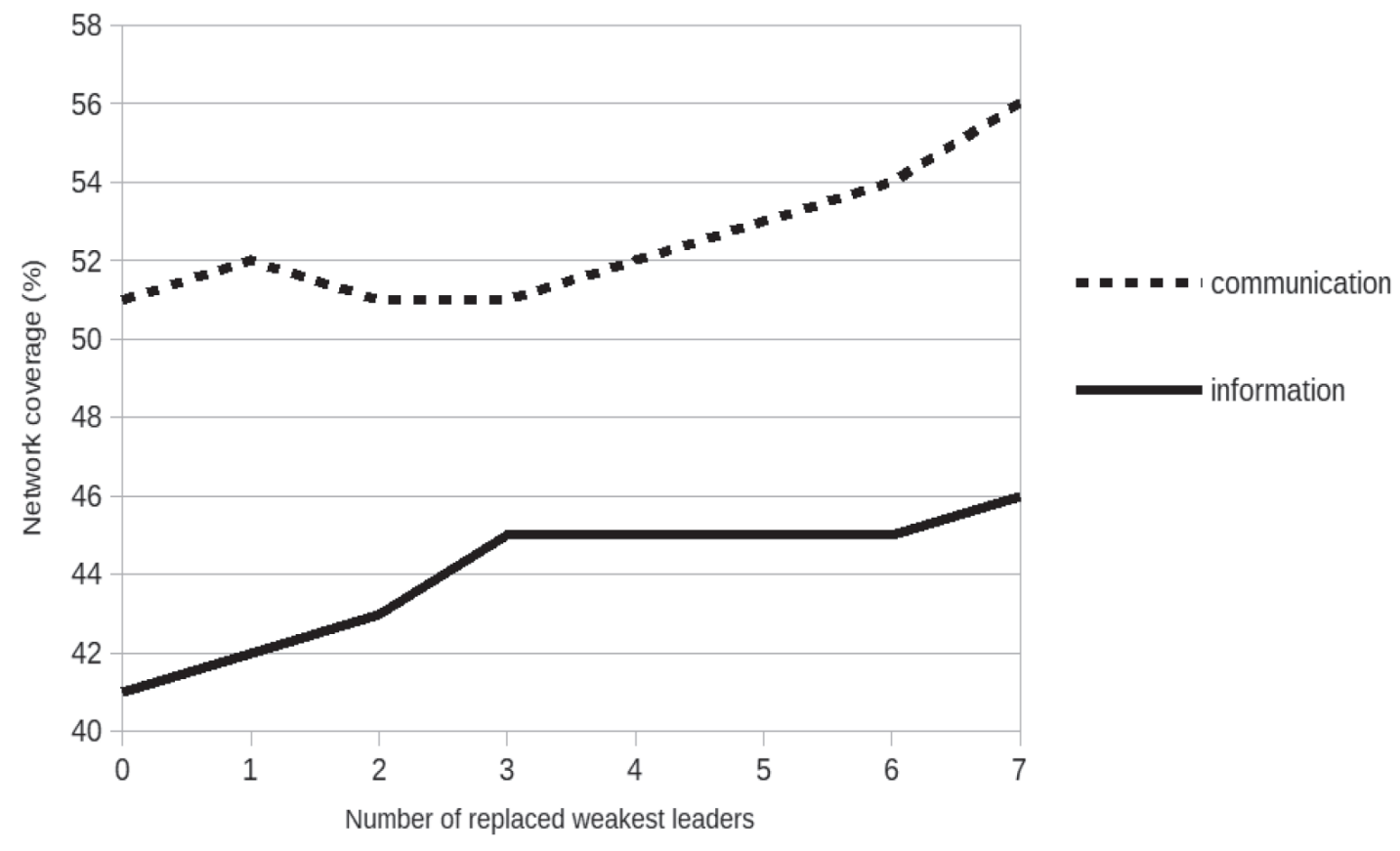

Fig. 5. Network coverage for 20 network nodes with a different number of replaced weakest, originally selected archetypical leaders 


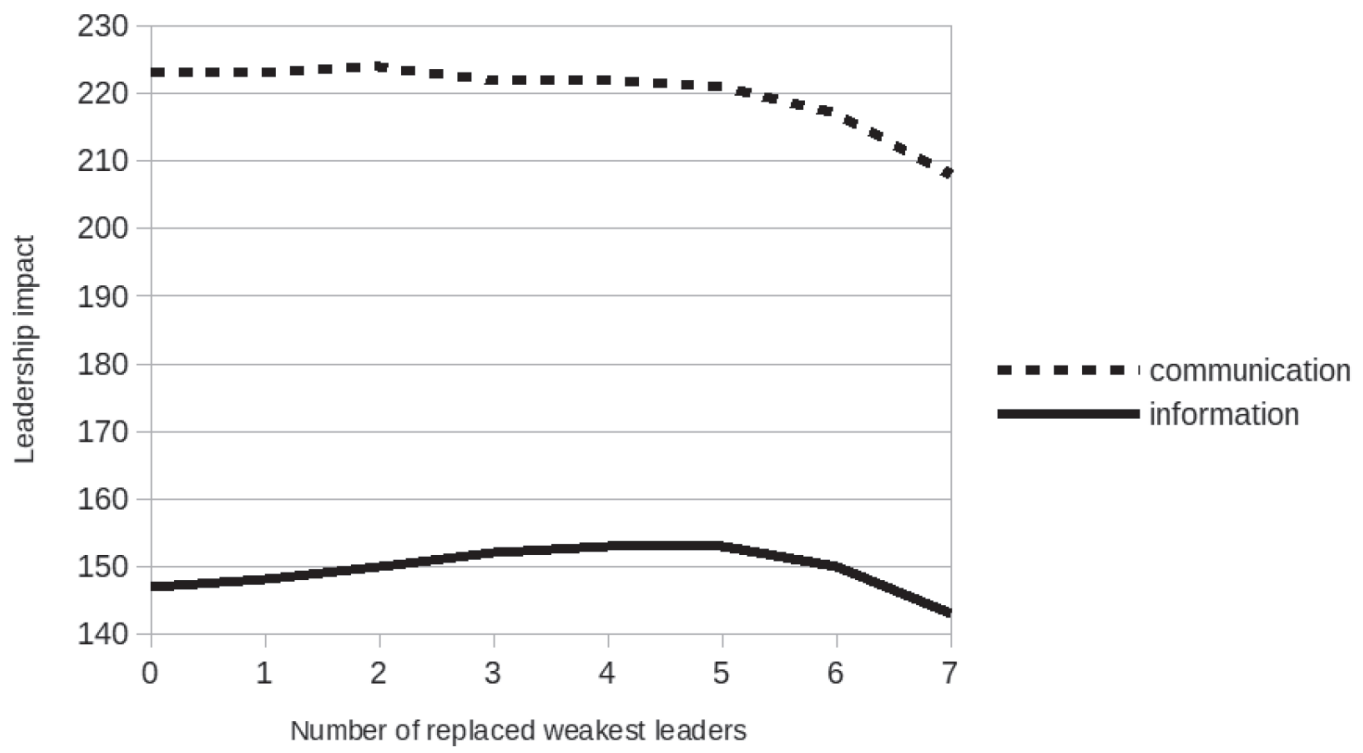

Fig. 6. Leadership impact for 20 network nodes with different number of replaced weakest, originally selected archetypical leaders

Source: author's own work.

even notice some improvement from 147 to 153 , which is more than $4 \%$.

\section{Discussion}

It is worth noting that it is always very important to understand the context of a change. Sometimes when organizational change concerns the improvement of some process, the crucial point of interest could be the collaboration network, for instance. In this situation the change is characterized as an evolutionary phenomenon rather than a revolutionary one. The change could be considered revolutionary in terms of implementing a completely new initiative, based on the innovative way of doing things. Those two described organizational changes are definitely different in nature, therefore should be treated differently. There could be the need to deeply understand how the employees trust each other in order not to boycott the initial preparations to the a challenging innovation, which is going to alter longused practices, break common processes, and force the changes in the way of the employees' thinking. For the reasons mentioned, there could be potentially different needs for selecting proper change leaders. Another important aspect to mention is the group of employees that ought to be covered by the change. Very often an organizational change is dedicated not to the all the employees but only to a specific group of them: some departments, silos, or projects. In such a situation more sophisticated algorithms, including knowledge about the context of the change, must be used in order to identify the proper change leaders.
Figure 7 sheds some light on two of the possible networks (the collaboration network and trust network) that could be taken into consideration depending on the context of the organizational change.

One of the possible future research directions includes applying the presented approach to a larger number of companies. Even though the analysed company is rather extensive research, it could take into consideration even bigger enterprises and definitely more of them. The other aspect worth further research is the assumption made at the beginning of this study, namely to consider a change as a one step process. Even though the initial phase of the change analysed in this paper could be an explanation for such assumptions, it is important to extend the research to include more than one step of diffusion. Moreover, the same assumption is applied to the term 'network coverage'. Potentially, reachability might be extended not only to the direct connections between the actors.

The entire study is focused on the initial phase of the organizational change. This opens the field for further research. Probably during the implementation of a change some other informal networks, different than one of those mainly considered in the study, would play a more crucial role and therefore ought to become a subject for future research.

Nevertheless, organizations that would like to increase the chances of a successful transformation must be aware of informal networks that exist beneath their formal, hierarchical structures. The ability to gain benefits from the existence of such layers seems to be an advantage in modern highly competitive markets. The presented approach of identifying potential 


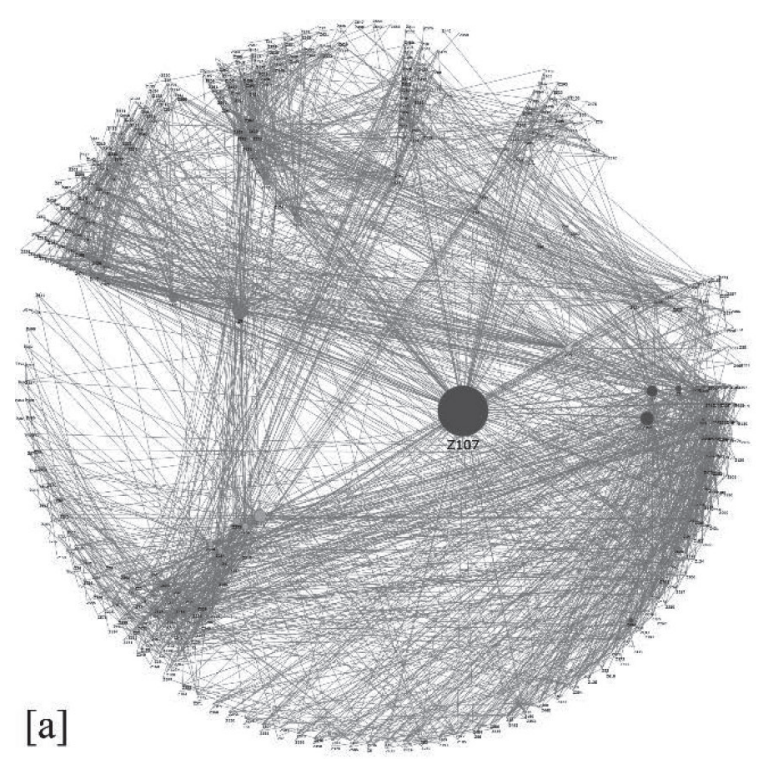

Fig. 7. (a) Collaboration Network; (b) Trust Network

Source: author's own work.

change leaders seems to be useful and might be a tool that would be used by companies preparing organizational change. However, some practical research should be conducted in the future, involving the analysis of the complete process of real organizational change.

\section{Bibliography}

Battista G.D., Eades P., Tamassia R., Tollis I.G., 1998, Graph Drawing: Algorithms for the Visualization of Graphs, Prentice Hall PTR.

Beckhard R., Harris R., 1987, Organizational Transitions: Managing Complex Change, Addison-Wesley, Reading.

Bełz G., 2011, System zarzadzania jako regulator odnowy i wzrostu przedsiębiorstw, Wydawnictwo Uniwersytetu Ekonomicznego we Wrocławiu, Wrocław.

Burt R.S., 1999, The social capital of opinion leaders, Annuals of the American Academy of Political and Social Science, 566, pp. 37-54.

Cross R.L., Paise S., Weiss L.M., 2007, The role of networks in organizational change. Companies shouldn't focus so much on formal structures that they ignore informal ones, McKinsey Quarterly, (April). Retrieved from: http://www.mckinsey. com/insights/organization/the role of networks in organizational change

De Chiara R., Erra U., Scarano V., 2003, VENNFS: a Venn-diagram file manager, Information Visualization, pp. 120-125.

Dunne C., Shneiderman B., 2009, Improving Graph Drawing Readability by Incorporating Readability Metrics: A Software Tool for Network Analysts University of Maryland (2009), HCIL Tech Report HCIL-2009-13.

Foucault Welles B., Xu W., 2018, Network visualization and problem-solving support: a cognitive study, Social Networks, vol. 54, pp. 162-167.

Frantz T.L., Carley K.M., 2005, Treemaps as a tool for social network analysis, DTIC Document, Tech. Rep., pp. 1-22, http:// dx.doi.org/10.2139/ssrn.2726843 .

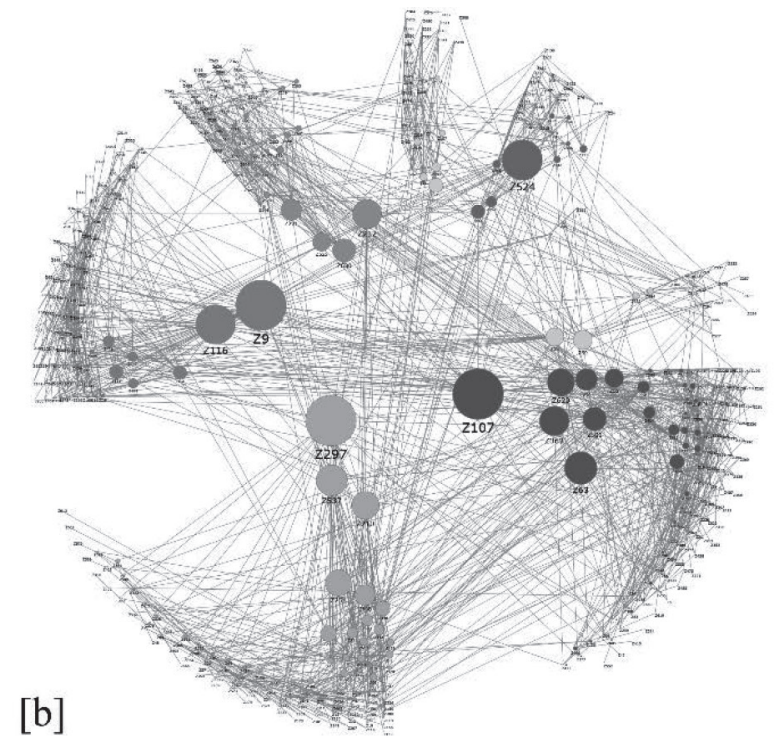

Fruchterman T., Reingold E., 1991, Graph drawing by forcedirected placement, Softw. - Pract. Exp., 21(11), pp. 1129-1164 .

Godes D., Mayzlin D., 2009, Firm-created word-of-mouth communication: evidence from a field test, Marketing Science, 28, pp. 721-739.

Goel S., Watts D.J., Goldstein D.G., 2012, The structure of online diffusion networks, Proceedings of the 13th ACM Conference on Electronic Commerce, pp. 623-638.

Gronn P., 2002, Distributed leadership as a unit of analysis, Leadership Quarterly, 13, pp. 423-451.

Herman I., Melancon G., Scott Marshall M., 2000, Graph visualization and navigation in information visualization: a Survey, Information Visualization, pp. 120-125.

Jacobs R.L., Russ-Eft D., 2001, Cascade training and institutionalizing organizational change, Advances in Developing Human Resources, 3(4), pp. 496-504.

Jasińska M., 2010, Udział menadżera w sprawnym zarzadzaniu organizacja oparta na wiedzy, Zeszyty Naukowe Akademii Podlaskiej w Siedlcach, series: „Administracja i Zarządzanie", nr 84.

Kamada T., Kawai S., 1989, An algorithm for drawing general undirected graphs, Information Processing Letters, 31(1), pp. 7-15. Retrieved from http://dx.doi.org/10.1016/00200190(89)90102-6.

Kanter R.M., 1983, The Change Masters: Corporate Entrepreneurs at Work, Simon \& Schuster, New York.

Katz E., Lazarsfeld P.F., 1955, Personal Influence: the Part Played by People in the Flow of Mass Communications, The Free Press, New York.

Kobourov S.G., 2012, Spring embedders and force directed graph drawing algorithms, arXiv preprint arXiv:1201.3011, http:// arxiv.org/abs/1201.3011.

Kotter J.P., 1996, Leading Change, Harvard Business School Press, Boston, MA.

Krackhardt D., 1993,The strength of strong ties: The importance of silos in organizations, [in:] N. Nohria, R. Eccles (eds), Networks and Organizations: Structure, Form, and Action, Harvard Business School Press, Boston, pp. 216-239. 
Kroenke A., 2016, Menedżer w zmieniającej się organizacji - ujęcie teoretyczne, Przedsiębiorczość i Zarządzanie/Entrepreneurship and Management, 2016, t. 17, z. 4, cz. 3, pp. 287-298.

Lippitt R., 1958, The Dynamics of Planned Change, Harcourt Brace, New York.

Maitlis S., Sonenshein S., 2010, Sensemaking in crisis and change: inspiration and insights from Weick (1988), Journal of Management Studies, 47(3), s. 551-580, doi: 10.1111/ j.1467-6486.2010.0090.

Marsden P.V., Friedkin N.E., 1993, Statistical difficulties of social influence, Sociological Methods and Research, 22, pp. 127-151.

McGrath C., Blythe J., Krackhardt D., 1997, The effect of spatial arrangement on judgements and errors in interpreting graphs, Soc. Netw., 19(3), pp. 223-242.

Ober J., 2013, Funkcja i rola efektywnej komunikacji w zarządzaniu, Zeszyty Naukowe Politechniki Śląskiej, series: Organizacja i Zarządzanie, z. 65.

Oreg S., 2006, Personality, context, and resistance to organizational change, European Journal of Work and Organizational Psychology, 15(1), pp. 73-101, doi:10.1080/ 13594320500451247

Oreg S., Vakola M., Armenakis A., 2011, Change recipients' reactions to organizational change: a 60-year review of quantitative studies, The Journal of Applied Behavioral Science, 47(4), s. 461-524. doi:10.1177/0021886310396550.

Purchase H.C., 1998, Performance of layout algorithms: comprehension not computation, J. Vis. Lang. Comput., 9(6), pp. 647-657.

Rostek K., Młodzianowski D., 2018, The impact of conscious and organized change management on efficiency of functioning the network organization, Management and Production Engineering Review, 49(3), https://doi.org/10.24425/119534.

Saleem A., Naveed S., 2017, Leadership and employees reaction towards change: role of leaders' personal attributes and transformational leadership, Pakistan Administrative Review, 1(1), pp. 61-83.

Sathiyanarayanan M., Burlutskiy N., 2015, Design and evaluation of Euler diagram and Treemap for social network visu- alization, 7th International Conference on Communication Systems \& Networks, 2015, pp. 1-6.

Smith M.E., 2002, Success rates for different types of organizational change, Performance Improvement, 41(1).

Sobka M., 2014, Zmiany organizacyjne w teorii i praktyce, Politechnika Lubelska.

Valente T.W., Pumpuang P., 2007, Identifying opinion leaders to promote behavior change, Health Education Behavior, 34(6), pp. 881-896.

Van de Ven A.H., 1986, Central problems in the management of innovation, Management Science, 32, pp. 590-607.

Watts D.J., Dodds P.S., 2007, Influentials, networks, and public opinion formation, Journal of Consumer Research, 34(4), pp. 441-458.

Wawrzynek Ł., 2017, Analiza sieci społecznych $w$ identyfikacji $i$ wzmacnianiu potencjalu innowacyjnego zespołów pracowniczych, Research Papers of the Wrocław University of Economics, Prace Naukowe Uniwersytetu Ekonomicznego we Wrocławiu, Issue 496, pp. 183-204

Weick K.E., 1995, Sensemaking in organizations, SAGE, Thousand Oaks, CA.

Whelan-Berry K.S., Somerville K.A., 2010, Linking change drivers and the organizational change process: a review and synthesis, Journal of Change Management, 10(2), pp. 175-193.

Willmanowicz E., 2012, Przywództwo, jako kluczowa rola Top Managementu we współczesnych organizacjach, Studia i Prace Wydziału Nauk Ekonomicznych i Zarządzania, nr 30.

Zak B., Zbieg A., 2014, Heuristic for network coverage optimization applied in finding organizational change agents, The 2014 IEEE/ACM European Network Intelligence Conference, http://dx.doi.org/10.1109/ENIC.2014.22.

Zbieg A., Batorski D., Żak B., 2016, How to Select Change Agents in Organizations? A Comparison of the Classical and Network Approaches / Jak wybrać agentów zmian w organizacji? Porównanie metod klasycznych i sieciowych, Problemy Zarządzania (4), doi: 10.7172/1644-9584.64.7.

\section{IDENTYFIKACJA POTENCJALNYCH LIDERÓW ZMIANY Z WYKORZYSTANIEM WIZUALIZACJI SIECI SPOLECZNYCH}

Streszczenie: Każda zmiana w organizacji uznawana jest za duże wyzwanie. Zapewnienie odpowiednich zasobów do jej przeprowadzenia jest rzeczą niezwykle istotną, tak samo jak zidentyfikowanie osób wewnątrz organizacji, które będą mogły skutecznie ją przeprowadzić Zarządcza analiza sieci organizacyjnych dostarcza pewnych metod i technik, które pozwalają na wizualizację nieformalnych struktur organizacyjnych. W niniejszym opracowaniu przedstawiono niektóre z nich, z położeniem nacisku na identyfikację potencjalnych liderów zaplanowanej do przeprowadzenia zmiany. W zaprezentowanym studium przypadku zbadano jedną dużą firmę, na której przykładzie analizowano pokrycie sieci przez wybraną grupę liderów zmiany. Celem artykułu jest analiza problemu doboru odpowiednich osób do kierowania zmianą. Do konstrukcji algorytmu selekcji potencjalnych liderów zmiany wzięto pod uwagę dwa czynniki: natężenie wartości archetypu liderskiego aktora oraz pozycję aktora w dwóch badanych sieciach nieformalnych. Wyniki potwierdzają spostrzeżenie, że stosunkowo niewielka grupa liderów może dotrzeć bezpośrednio do większości pracowników, co jest jednym z kluczowych czynników, aby zmiana zakończyła się sukcesem. Wizualizacje wykorzystane w badaniu mogą skrócić czas poszukiwań odpowiednich osób do kierowania zmianą, a dodatkowo zniwelować prawdopodobieństwo nietrafionych wyborów.

Słowa kluczowe: zmiana w organizacji, analiza sieci organizacyjnych, wizualizacje sieci. 